\title{
УСЛОВИЯ ФОРМИРОВАНИЯ И ВОЗРАСТ РЕДКОМЕТАЛЬНОГО ОРУДЕНЕНИЯ КУКУЛЬБЕЙСКОГО РУДНОГО РАЙОНА (ВОСТОЧНОЕ ЗАБАЙКАЛЬЕ)
}

\author{
Редина Анна Андреевна',
}

redina@igm.nsc.ru

\author{
Мокрушников Виктор Павлович', \\ viktorm@igm.nsc.ru \\ Редин Юрий Олегович', \\ redin@igm.nsc.ru \\ Институт геологии и минералогии им. В.С. Соболева СО РАН, \\ Россия, 630090, г. Новосибирск, пр. Академика Коптюга, 3.
}

Актуальность. Определение современными методами условий формирования редкометального оруденения на примере типовых месторождений Кукульбейского рудного района, в совокупности с изотопно-геохронологическими исследованиями являются ключевыми аспектами в решении одной из важнейших фундаментальных проблем рудной геологии и геохимии - выяснение условий, источников, механизмов и последовательности формирования рудных концентраций металлов в различных геологических обстановках.

Цель: получение новых данных о физико-химических условиях формирования редкометального оруденения, а также установление возраста оруденения.

объекты: Букукинское, Белухинское и Антоновогорское месторождения.

Методы. Флюидные включения были изучены в прозрачно-полированных пластинках методами крио-термометрии и Рамановской спектроскопии. Крио-термометрические исследования выполнялись в микротермокамере THMSG-600 фирмы Linkam. O6разцы последовательно охлаждались до температуры $-190{ }^{\circ} \mathrm{C}$ и нагревались до полной гомогенизации вещества включений. В процессе наблюдения замерялись температуры эвтектики, плавления льда и гомогенизации. Температуры плавления льда для двухфазных и температуры плавления кристалликов соли для трехфазных флюидных включений позволили установить концентрацию солей в пересчете на $\mathrm{NaCl}$-эквивалент. Состав газовой и минеральной фаз флюидных включений изучался методом Рамановской спектроскопии - спектрометр Ramanor U-1000 и детектор Horiba DU42OE-OE-323 фирмы Jobin Yvon, лазер Millennia Pro фирмы Spectra-Physics; Confocal Raman Microscope alpha 300R фирмы WITec. ${ }^{40} \mathrm{Ar} /{ }^{\beta 9} \mathrm{Ar}$ метод изотопно-геохронологического датирования по методике ступенчатого прогрева применялся для установления абсолютного возраста оруденения.

Результаты. Рудные минеральные ассоциации рассматриваемых месторождений сформировались при участии хлоридных высокотемпературных флюидов, насыщенных углекислотой. Повсеместно рудоносные флюиды содержат восстановленные газы, из которых превалирует метан, а сероводород, азот и водород находятся в подчиненном количестве. В рамках кристаллизации отдельных минеральных ассоциаций прослеживается эволюция рудоносного флюида: снижение температуры и концентрации растворов. Катионный состав растворов также изменился от существенно натрового до существенно калиевого. Для объектов исследования получены умеренные оценки глубин: 6-8 км для Букукинского, 4,5-6 км для Белухинского и 3-3,5 км для Антоновогорского месторождения. Возраст редкометального оруденения составляет на Антоновогорском месторождении 146,7士1,7 млн лет (мусковит из кварц-мусковитовых грейзенов с вольфрамитом); на Букукинском месторождении $135 \pm 2,8$ млн лет (серицит из кварц-вольфрамитовых жил); на Белухинском месторождении - 155,6士1,8млн лет (серицит из кварц-вольфрамитовых жил).

Выводы. Редкометальная минерализация Кукульбейского рудного района, на примере типовых месторождений, формировалась из высокотемпературных гидротермальных насыщенных восстановленными газами (метан, сероводород, азот и водород) углекислотно-водно-хлоридных растворов магматического происхождения. По глубине становления рассматриваемые рудоносные системы можно отнести к гипабиссальным от 8 до 3 км. Проведенные изотопно-геохронологические исследования показали, что в пределах Кукульбейского рудного района формирования вольфрамового оруденения происходило в позднеюрское-раннемеловое время, основная часть которого связана со становлением магматических пород кукульбейского комплекса, не исключено что позднеюрское оруденение связано со становлением магматических пород шахтаминского комплекса.

\section{Ключевые слова:}

Редкометальные месторождения, возраст, условия формирования, связь с магматизмом, Восточное Забайкалье.

\section{Введение}

Кукульбейский рудный район расположен в юго-восточном Забайкалье, в Агинской тектонической зоне и содержит крупные минеральные ресурсы вольфрама, позволяющие считать этот рудный район самостоятельной минерально-сырьевой базой вольфрама Забайкалья. Они сосредоточены главным образом на рудных полях, месторождениях Букука-Белухинского рудного узла и отчасти Этакинского. В этом старейшем рудном районе в сороко- вых-пятидесятых годах эксплуатировались Букукинское, Белухинское, Антоновогорское и другие месторождения. В металлогеническом отношении Агинская зона известна как область наиболее широкого в регионе развития редкометального оруденения. Пространственно и генетически редкометальное оруденение связано с многочисленными массивами кукульбейского $\left(\mathrm{J}_{3}\right)$ лейкогранитового комплекса. Наряду с массивами гранитов кукульбейского комплекса в Агинской зоне широко развиты 
небольшие интрузии шахтаминского $\left(\mathrm{J}_{2}-\mathrm{J}_{3}\right)$ комплекса габбро-диорит-монцодиорит-гранодиоритового состава [1]. Основную часть вольфрамового оруденения несут кварцевые жилы с грейзенированными зальбандами и штокверки, меньшую часть - кварц-мусковитовые, кварц-топазовые, кварц-турмалиновые и другие грейзены. При этом имеются все переходные типы от собственно грейзеновых к собственно кварцевым рудным телам. Чаще всего минеральные ассоциации в большинстве (пунктов минерализации) рудопроявлений однородны и представлены: вольфрамитом, касситеритом, молибденитом, арсенопиритом, пиритом, пирротином, висмутином, бериллом, флюоритом др. Некоторые отличия были обнаружены лишь в месторождениях с более сложным составом и нередко значительной ролью сульфидов молибдена, свинца, цинка, меди, мышьяка, и других элементов.

Месторождения Восточного Забайкалья рассматривались в работе Е.М. Лазько и др. [2], посвященной выявлению некоторых важнейших физико-химических аспектов генезиса месторождений и выработке поисковых термобарогеохимических критериев, вместе с другими объектами Средней Азии, Северного Кавказа, Рудного Алтая и Забайкалья. В книге приведены результаты исследований, проведенных с использованием актуальных методов и технологий на момент публикации: гомогенизации, декрипитации и криометрии включений, водных и газовых вытяжек. Объекты, обсуждаемые в работе Лазько и др., были рассмотрены не индивидуально, а как члены ряда однотипных месторождений. В данной работе исследовались Букукинское, Белухинское и Антоновогорское месторождения. По которым приводится детальное описание физико-химических условий формирования, полученное современными методами термобарогеохимии, по отдельным рудным минеральным ассоциациям. Предварительные результаты изучения флюидных включений редкометальных месторождений Восточного Забайкалья изложены в работе А.А. Редина и др. [3].

\section{Геологическое строение}

Букука-Белухинский рудный узел охватывает территорию, расположенную на стыке оловянновольфрамового и золото-молибденового рудных поясов, выделенных С.С. Смирновым. В пределах рудного узла наиболее широко развиты разломы северо-восточного простирания, участки их пересечения с разломами северо-западного направления определяют положение локальных очаговокупольных структур (Букукинской, Белухинской), инрузивных массивов и вольфрамового оруденения. В Букука-Белухинском рудном узле один из главных рудоконтролирующих факторов связь вольфрамового оруденения с гранитоидами кукульбейского интрузивного комплекса. Площади, на которых отсутствуют проявления специфических гранитных образований, соответственно лишены рудной минерализации. Границей рудно- го узла является проекция рудоносных массивов гранитов, в том числе не вскрытых эрозией и отмечающихся гравитационными минимумами.

Биотитовые и лейкократовые граниты и гранит-порфиры рудоносного кукульбейского комплекса слагают дайки и небольшие штокообразные тела в пределах Белухинского и Букукинского массивов гранитоидов, в том числе и в районе одноименных вольфрамовых месторождений. Исследователями установлено, что гранит-порфиры поздней рудоносной фазы в пределах Букука-Белухинского рудного узла пользуются гораздо более широким развитием, чем это считалось ранее. Значительная часть рудоносных гранитоидов залегает на глубине, то есть в целом Букука-Белухинский плутон имеет двухярусное строение [4].

Букукинское месторождение (рис. 1) занимает площадь около $6 \mathrm{kм}^{2}$, хотя вообще вольфрамовое оруденение фиксируется и в ближайших его окрестностях, распространяясь на площади до $10 \mathrm{kм}^{2}$. Месторождение сложено гранодиоритами шахтаминского интрузивного комплекса. Известно, что вышеупомянутые гранитоиды являются пассивными по отношению к продуктивному вольфрамовому оруденению. Собственно вольфрамовое оруденение связывается с невскрытым куполом кукульбейских гранитоидов, проявления которых имеются и на поверхности. На месторождении развиты два типа руд: кварц-гюбнерит-сульфидный и вольфрамитсодержащих грезейнов. Жилы сосредоточены среди среднеюрских гранодиоритов шахтаминского интрузивного комплекса. Протяженность жил составляет от 50-800 до 1500-2000 м, мощность до 2-3 м. Они вскрыты горными выработками до глубины 230 м, буровыми скважинами до 400 м и более. Кроме вольфрама в них содержится висмут до $1 \%$, сульфиды меди, свинца и железа. Околожильные изменения выражены в интенсивной грейзенизации. Вольфрамоворудные грейзены Букукинского месторождения находятся на двух участках и имеют площадное распространение. На участке «Грейзеновое поле» они мусковитовые, кварц-мусковитовые, кварц-топазовые. Восточный участок грейзенов приурочен к сравнительно пологому $\left(20-40^{\circ}\right)$ контакту штока позднеюрских кварцевых порфиров с гранодиоритами шахтаминского комплекса и перекрывающих их метаморфизованных глинистых сланцев. Грезейны преимущественно кварцевые. Руды штокверковые и представлены вольфрамитом, молибденитом, сфалеритом, иногда шеелитом, висмутином, халькопиритом, бериллом и литиеносными слюдами. Штокверк располагается в зоне трещиноватости, предположительно связанной с апикальным выступом Букукинского гранитного массива, прослеживается в северо-восточном направлении на 160 м при ширине 60 м.

Белухинское месторождение (рис. 1) расположено в экзоконтактовой зоне одноименного гранитного массива (в 17 км на северо-восток от Букукинского). Содержит 114 кварц-вольфрамитовых 
жил. Крутопадающие рудные тела имеют длину от 45 до 765 м, мощность $0,1-0,5$ м. Околорудные изменения выразились в грейзенизаци, окварцевании и березитизации.

Главные рудные минералы - вольфрамит и шеелит, попутные - висмутин и молибденит. Помимо самого месторождения, в окрестностях выделены ещё несколько участков, на которых имеются площадные грейзены по гранитоидам кукульбейского комплекса. В них установлены содержания вольфрама, свинца и фтора до $1 \%$, лития - 0,3\% [5]. Проведенные в последнее время петрохимические и геохимические исследования магматических пород Белухинского массива подтвердили неоднократно отмечавшуюся ошибочность отнесения их на геологических картах к шахтаминскому комплексу. Проведенный комплекс исследований показал, что магматические породы Белухинского массива относятся к кукульбейскому комплексу [1].
Антоновогорское месторождение (рис. 1) входит в состав Этыкинского рудного узла, приурочено к контакту одноименного гранитного массива кукульбейского комплекса с нижнеюрскими отложениями и представляет собой главным образом объект жильного типа. На площади месторождения найдено более 200 кварц-вольфрамитовых и кварц-вольфрамит-сульфидных жил с северо-восточным направлением, крутыми углами падения $\left(75-80^{\circ}\right)$ на северо-запад и протяжённостью от 45 до 560 м (иногда до 700 м), с мощностями от 0,2 до 1,51 м. Среднее содержание вольфрама в рудах $0,5 \%$. Главный жильный рудный минерал - вольфрамит, в осадочных породах - касситерит, также встречаются: шеелит, халькопирит, пирит, арсенопирит, берилл, висмутин, пирротин, сфалерит, марказит. Наиболее распространённые околожильные изменения: окварцевание и грейзенизация [5].

Pис. 1. Фраглент геологической карты М-50-ІХ с дополненияли авторов: 1 - четвертичные отложения; 2 - ножийская свита: галечники и валунники; 3 - верхнегазимурская свита: конгломераты с прослояли и линзали гравелитов, песчаников, хлидолитов; 4- кавыкучинская свита: переслаивание конгломератов, песчаников, гравелитов и алевролитов; 5 - государевская свита: песчаники, алевролиты; 6 - сивачинская свита: конгломераты, гравелиты, прослои и пачки песчаников; 7 - таленгинская свита: песчаники, алевролиты, аргиллиты; 8 - икагийская свита: алевролиты, аргиллиты, песчаники, хлидолиты, в основании дресвяники, гравелиты, конгломераты; 9 - соктуйская свита: песчаники, туфопесчаники, конглолераты, конгломерато-брекчии, гравелиты, алевролиты; 10 - антиинская свита: песчаники, туфопесчаники, алевролиты, аргиллиты, конгломераты; 11 - газимурозаводская (?) свита: квариево-слюдистые сланиы, мрамора; 12,13-кукульбейский колплекс: 12 - литионит-алазонит-альбитовые граниты $\left(\gamma_{2}\right) ; 13$ - граниты, лейкограниты $\left(\gamma_{1}\right) ; 14-16$ шахтаминский комплекс: 14 - граниты $\left(\gamma_{3}\right) ;$ гранит-порфиры $\left(\gamma \pi_{3}\right) ; 15$ - гранодиориты $\left(\gamma \delta_{2}\right)$, граносиениты $\left(\gamma \xi_{2}\right)$, квариевые мониодиориты $\left(q \mu_{2}\right)$, квариевые диориты $\left(q \delta_{2}\right)$; 16 - квариевые монцодиориты $\left(q \mu_{1}\right) ; 17-19$ ундинский колплекс: 17 - граниты $\left(\gamma_{3}\right) ; 18$ - гранодиориты $\left(\gamma \delta_{2}\right)$, квариевые диоpиты $\left(q \delta_{2}\right) ; 19$ - габбро ( $\left.v_{1}\right)$, диориты $\left(\delta_{1}\right) ; 20$ - урульгинский колплекс метаморфический: алфиболиты $(\alpha) ; 21$ - квариевые диориты; 22 - квариевые мониодиориты; 23 - контактовые роговики и ороговикованные породы, тектониты; 24 - динамолеталорфизованные породы филлиты и эпидот-хлоритовые сланиы; 25, 26 - метасоматиты и метасоматически изменённые породы: 25 - внемасштабные тела: березиты, грейзены; 26 - грейзены; 27 - геологические границы между разновозрастныли подразделениями и телами разного состава внутри них: а) достоверные, б) предполагаемые; 28 - несогласное залегание: а) достоверные, б) предполагаелье; 29 - несогласное залегание между фациально разныли образованияли; 30 - структурные швы сложной кинелатики с преобладаниел листрических взбросов и надвигов; 31-35 - разломы второго порядка: 31 - надвиги: а) достоверные, б) предполагаелые; 32 - взбросы и крутые надвиги: а) достоверные, б) предполагаелые, в) скрытые под вышележащили образованияли, достоверные; 33 - сдвиги: а) левые, б) правые; 34 - сбросы (с указаниел наклона слестителя): а) достоверные, б) предполагаемые, в ) скрытые под вышележащили образованияли, достоверные; 35 - разломы второго порядка неустановленной кинематики: а) достоверные, б) предполагаелые, в) скрытые под вышележащили образованияли, достоверные. Черныли квадратами показаны объекты исследования: I - Белухинское месторождение; II - Букукинское месторождение; III - Антоновогорское месторождение

Fig. 1. Fragment of the geological map M-50-IX with the authors' additions: 1 - quaternary sediments; 2 - nozhisky formation: pebbles and boulders; 3 - verkhnegazimursky formation: conglomerates with interlayers and lenses of gravelites, sandstones, hlidolites; 4 - kavykuchinsky formation: interbedding of conglomerates, sandstone, gravel and siltstones; 5 - gosudarevsky formation: sandstones, siltstones; 6 - sivashinsky formation: conglomerates, gravel, interlayers and bundles of sandstones; 7 - tamengsky formation: sandstones, siltstones, mudstones; 8 - ikagiysky formation: siltstones, mudstones, sandstones, hlydoliths, in the basement dregs, gravelites, conglomerates; 9 - soktuisky formation: sandstones, tuff sandstones, conglomerates, conglomerate-breccias, gravelites, siltstones; 10 - antiinsky formation: sandstones, tuff sandstones, siltstones, argillites, conglomerates; 11 - gazimurozavodsky (?) formation: quartz-micaceous shales, marble; 12, 13 - Kukulbeisky complex: 12 - lytonite-amazonite-albite granites $\left(\gamma_{2}\right) ; 13$ - granites, leucogranites $\left(\gamma_{1}\right)$; 14-16 - Shakhtama complex: 14 - granites $\left(\gamma_{3}\right)$; granite-porphyry $\left(\gamma \pi_{3}\right) ; 15$ - granodiorites $\left(\gamma \delta_{2}\right)$, granosyenites $\left(\gamma \xi_{2}\right)$, quartz monzodiorites $\left(q \mu_{2}\right)$, quartz diorites $\left(q \delta_{2}\right) ; 16$ - quartz monzodiorites $\left(q \mu_{1}\right) ; 17-19$-Undine complex: 17 - granites $\left(\gamma_{3}\right) ; 18-$ granodiorites $\left(\gamma \delta_{2}\right)$, quartz diorites $\left(q \delta_{2}\right) ; 19$ - gabbro $\left(v_{1}\right)$, diorites $\left(\delta_{1}\right) ; 20$-Urulginsky metamorphic complex: amphibolites $(\alpha) ; 21-q u a r t z$ diorites; 22 - quartz monzodiorites; 23 - contact hornfels and hornfels, tectonites; 24 - dynamo-metamorphized rocks, phyllites and epidote-chlorite schists; 25, 26 - metasomatites and metasomatically altered rocks: 25 - out-of-scale bodies: berezites, greisens; 26 - greisens;27 - geological boundaries between different age divisions and bodies of different composition within them: a) reliable, б) assumed; 28 - unconformity: a) reliable, $b$ ) assumed; 29 - disagreement between facies of different formations; 30 - structural seams of complex kinematics with predominance of lustretic ups and thrusts; 31-35-second-order faults: 31 - thrusts: a) reliable, б) assumed; 32 - ups and steep thrusts: a) reliable, б) assumed, в) hidden under the overlying formations, reliable; 33 - shifts: a) left, б) right; 34 - faults (indicating the slope of the displacer ): a) reliable, б) assumed, в) hidden in the overlying formations, reliable; 35 - second-order faults of unknown kinematics: a) reliable, б) assumed, 8 ) hidden under the overlying formations, reliable. The black squares show the objects of investigation: I - Belukha deposit; II - Bukuka deposit; III - Antonovogora deposit 


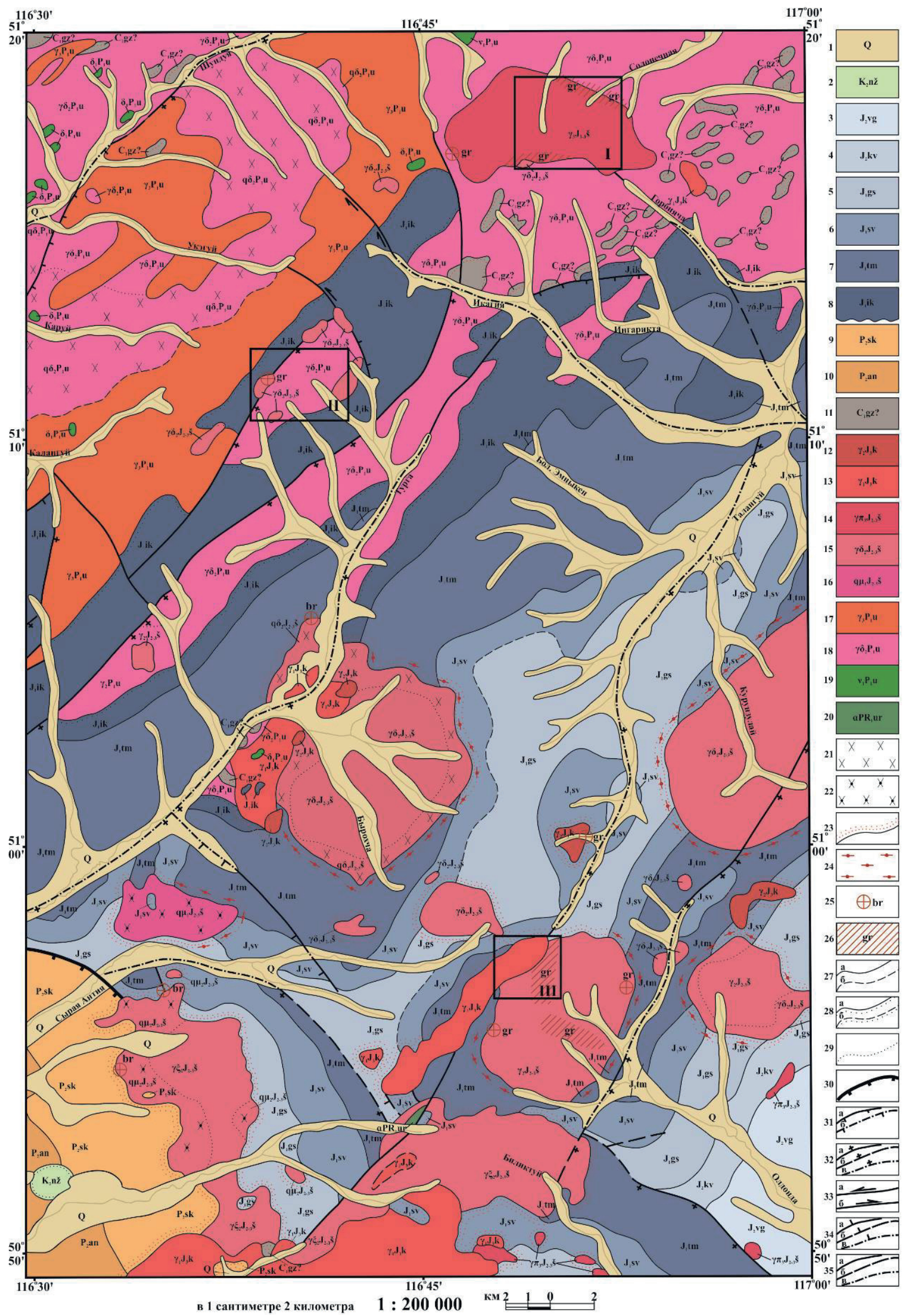




\section{Возраст оруденения}

Нами были проведены исследования возраста $\mathrm{K}$-содержащих минералов синрудных парагенезисов ${ }^{40} \mathrm{Ar} /{ }^{39} \mathrm{Ar}$ по методике ступенчатого прогрева, подробно описанной ранее [6]. Полученные возрастные спектры, представленные на рис. 2, могут интерпретироваться как ненарушенные.

Во всех спектрах выделяется плато, соответствующее критериям, предложенным в [7]. Возраст редкометального оруденения составляет на

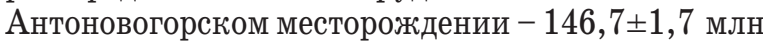
лет (мусковит из кварц-мусковитовых грейзенов с вольфрамитом); на Букукинском месторождении - $135 \pm 2,8$ млн лет (серицит из кварц-вольфрамитовых жил); на Белухинском месторождении - 155,6 $\pm 1,8$ млн лет (серицит из кварц-вольфрамитовых жил).

\section{Флюидные включения}

По оптическим наблюдениям при комнатной температуре для исследований были отобраны, используя критерии, изложенные в работе Э. Рёддеpa [8], первичные, псевдовторичные и вторичные флюидные включения (ФВ). Первичные ФВ изометричной, овальной или формы негативных кристаллов, размером от 5 до 15 мкм. Они наблюдаются в виде индивидуальных включений, реже образуют небольшие группы. Псевдовторичные ФВ имеют удлиненную или изометричную форму вакуоли и размеры 8-17 мкм. Такие включения локализуются в трещинках, залеченных в процессе роста кристалла-хозяина. Вторичные ФВ неправильной формы и размерами 10-25 мкм располагаются по более поздним трещинам, секущим несколько зерен минерала-хозяина. По фазовому со- ставу при стандартных условиях выделяются три вида ФВ: 1) VL (vapor-liquid) газово-жидкие; 2) VLC (vapor-liquid- $\mathrm{CO}_{2}$ liquid) газово-жидкие, содержащие углекислоту в жидкой форме; 3) VLS (vapor-liquid-solid), содержащие газовую, жидкую и твердую фазы. Исследования ФВ проводились на базе ИГМ СО РАН методами микротермометрии и Раман-спектроскопии. Крио-термометрические измерения осуществлялись при помощи термокамеры THMSG-600 фирмы Linkam. Интерпретация температур эвтектики газово-жидких ФВ проводилась согласно данным А.С. Борисенко [9]. Кроме того, для двухфазных ФВ концентрация растворов определялась по температуре плавления льда [10]. Давление флюида рассчитано посредством программы FLINCOR [11] с использованием температур гомогенизации $\mathrm{CO}_{2}$. Состав газовой фазы установлен на спектрометре Ramanor U-1000 с детектором Horiba DU420E-OE-323 фирмы Jobin Yvon, лазер Millennia Pro фирмы Spectra-Physics. Peзультаты всех термобарогеохимических измерений и расчетов приведены в таблице.

Букукинское месторождение. Рудная минерализация представлена бериллом, вольфрамитом, сульфидами $\mathrm{Fe}, \mathrm{Pb}$ и висмутином. Для исследования были отобраны образцы четырех минеральных ассоциаций: кварц-берилл-мусковитовые грейзены с вольфрамитом, пиритом и молибденитом (образцы Buk-2-1, Buk-2-2) I; кварцевые жилы с вольфрамитом и пиритом (образец Buk-1) II; кварцевые жилы с пиритом, галенитом и вольфрамитом (Buk-3-1, Buk-3-2) III; кварцевые жилы с висмутином, пиритом и вольррамитом (Buk-4) IV.

Вольфрамит минеральной ассоциации $I$ наблюдается в виде рассеянной вкрапленности и прожил-
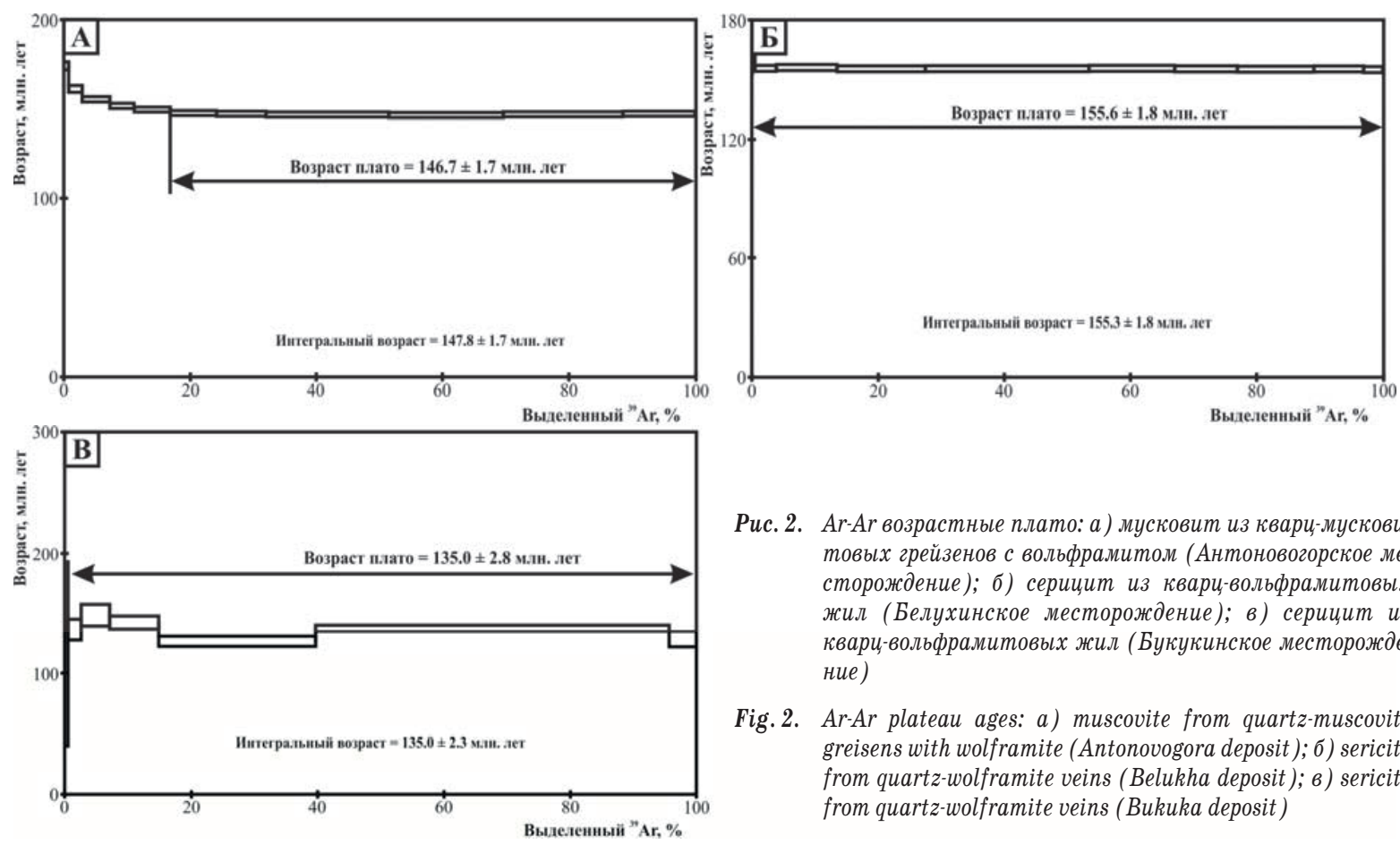

Puc. 2. Ar-Ar возрастные плато: а) мусковит из квари-мусковитовых грейзенов с вольфралитол (Антоновогорское месторождение); б) серицит из квари-вольфрамитовых жил (Белухинское месторождение); в) серицит из квари-вольфралитовых жил (Букукинское месторождение)

Fig. 2. Ar-Ar plateau ages: a) muscovite from quartz-muscovite greisens with wolframite (Antonovogora deposit); б) sericite from quartz-wolframite veins (Belukha deposit); в) sericite from quartz-wolframite veins (Bukuka deposit) 
ков. Первичные и псевдовторичные ФВ в кварце напрямую характеризуют процесс рудообразования. Первичные VL ФВ гомогенизируются в жидкость при высоких температурах $T_{\text {гом }} 350-390{ }^{\circ} \mathrm{C}$. Полученные температуры эвтектики $T_{\text {эвт }}-23 . . .-21^{\circ} \mathrm{C}$ указывают на присутствие в растворе хлоридов натрия и калия. Концентрация солей в растворе, по температурам плавления льда $T_{\text {пл }}-7 \ldots-5{ }^{\circ} \mathrm{C}$, эквивалентна 7,9-10,5 мас. \% NaCl-экв. Газовая фаза представлена смесью метана и углекислоты, в отдельных случаях с примесью азота и водорода. Для псевдовторичных VL ФВ получены средние температуры гомогенизации в жидкость $T_{\text {гом }} 250-280^{\circ} \mathrm{C}$ и относительно высокие температуры плавления льда $T_{\text {пл }}-6 . . .-2{ }^{\circ} \mathrm{C}$. По этим данным можно определить концентрацию солей, как равную 3,4-9,2 мас. \% NaCl-экв. В газовой фазе содержится преимущественно углекислота, редко с примесью метана.

Берилл кварц-берилл-мусковитовых грейзен $I$ трещиноватый почти бесцветный (с легким голубо-зеленым оттенком). В нем содержатся первичные и вторичные ФВ видов VL, VLC и VLS. Первичные ФB VL гомогенизируются в жидкую фазу при температурах $T_{\text {гом }} 240-320^{\circ} \mathrm{C}$. Температуры эвтектики $T_{\text {әвт }}-21 . . .-19{ }^{\circ} \mathrm{C}$ свидетельствуют о преобладании хлорида натрия в растворе. Судя по полученным температурам плавления льда $\left(T_{\text {пл }}-3,5 . .-1,5{ }^{\circ} \mathrm{C}\right)$ захваченный раствор слабосоленый 2,6-5,7 мас. \% NaCl-экв. В состав газовой фазы входят метан и углекислота, редко примесь азота и водорода. При нагревании первичных VLC ФB (рис. $3, a$ ) установлено, что углекислота гомогенизируется в газ при температурах $T_{\text {гом }} \mathrm{CO}_{2} 28-30{ }^{\circ} \mathrm{C}$, а полная гомогенизация включений происходит в жидкость при температурах $T_{\text {гом }} 250-280^{\circ} \mathrm{C}$. Полученным значениям соответствуют плотность углекислоты $\rho \mathrm{CO}_{2} \quad 0,34-0,42 \quad \Gamma / \mathrm{cm}^{3}$ и давление 2000-2100 бар. VLS ФВ являются первичными. Оптически выделяются две разновидности минеральных фаз: светлоокрашенные анизотропные (рис. 3, б) и очень мелкие темноокрашенные (вероятно, рудный минерал) (рис. 3, в). Светлоокрашенные твердые фазы представлены силикатами и, вероятно, являются ксеногенными. Идентифицировать темноокрашенные твердые фазы не удалось в виду их малых размеров. Газовая фаза является смесью углекислоты и метана. Температуры гомогенизации не установлены, в связи с растрескиванием включений в процессе нагревания. Вторичные VL ФВ, соответствующие позднему гидротермальному этапу минералообразования, гомогенизируются в жидкость при низких температурах $T_{\text {гом }} 140-190{ }^{\circ} \mathrm{C}$. Температуры плавления льда и соленость умеренные: $T_{\text {пл }}-5 . . .-2,5^{\circ}, 4,2$ до 7,9 мас. $\%$ $\mathrm{NaCl}$-экв. В составе газовой фазы доминирует углекислота, в качестве примеси отмечается метан.

Кварцевые жилы II содержат вольфрамитовую минерализацию в виде вкрапленности и прожилков. Для исследования отобраны первичные и псевдовторичные включения, являющиеся синге- нетичными рудным минералам. Температуры гомогенизации в жидкую фазу $T_{\text {гом }}$ первичных VL ФB (рис. 3, г) варьируют от 290 до $310{ }^{\circ} \mathrm{C}$. Температуры эвтектики $T_{\text {эвт }}-37 \ldots-28{ }^{\circ} \mathrm{C}$ и плавления льда $T_{\text {пл }}-6 . . .-5{ }^{\circ} \mathrm{C}$ соответствуют раствору с концентрацией солей 7,9-9,2 мас. \% NaCl-экв., представленных хлоридами натрия и железа. В составе газовой фазы содержатся углекислота и метан, редко азот. Псевдовторичные VL ФВ гомогенизируются в жидкость при температурах $T_{\text {гом }} 220-250{ }^{\circ} \mathrm{C}$. Солевой состав раствора по полученным температурам эвтектики $T_{\text {эвт }}-17 \ldots-14{ }^{\circ} \mathrm{C}$ хлоридный (хлориды натрия и калия). Концентрация солей соответствует температурам плавления льда $T_{\text {пл }}-4 . . .-0,5{ }^{\circ} \mathrm{C}$ и равна 0,9-6,5 мас. \% NaCl-экв. Газовая фаза преимущественно углекислотная с примесью метана.

Вольфрамит-галенит-пиритовая минерализация Букукинского месторождения локализована в кварцевых жилах $I I I$ в виде вкрапленности и прожилков, формированию которых соответствуют первичные и псевдовторичные ФВ в кварце. Первичные VL ФВ характеризуются умеренно высокими температурами гомогенизации $T_{\text {гом }} 285-325^{\circ} \mathrm{C}$ (в жидкость). Принимая во внимание $T_{\text {эвт }}-15 . .-10{ }^{\circ} \mathrm{C}$, можно определить, что в растворе присутствуют хлориды калия и натрия. Температуры плавления льда близки к нулю $\mathrm{T}_{\text {пл }}-1,5 \ldots-0,1{ }^{\circ} \mathrm{C}$, и концентрация солей составляет 0,2-2,6 мас. \% NaCl-экв. В составе газовой фазы преобладает углекислота, постоянно присутствует метан и сероводород (редко следы азота и водорода). Термометрия первичных ФВ вида VLC (рис. 3, ә) показала, что гомогенизация углекислоты происходит в газовую фазу при температурах $14-27^{\circ} \mathrm{C}$, полная гомогенизация наступает при температурах $295-310{ }^{\circ} \mathrm{C}$. Расчетные плотность углекислоты и давление составляют $\rho \mathrm{CO}_{2} \quad 0,15-0,27$ г/ $\mathrm{cm}^{3}$ и $1600-1700$ бар соответственно. Первичные VLS ФВ (рис. $3, e$ ) гомогенизируются при температурах $T_{\text {гом }} 365-390{ }^{\circ} \mathrm{C}$. Концентрация растворов этого типа включений составляет 43,8-46,4 масс. \% NaCl-экв. В газовой фазе VLS ФB содержатся углекислота, метан и сероводород, примесь азота. Псевдовторичные VL ФВ отличаются относительно низкими температурами гомогенизации в жидкость $190-260{ }^{\circ} \mathrm{C}$. Температуры эвтектики $T_{\text {эвт }}-9 . .-17^{\circ} \mathrm{C}$ указывают на присутствие в растворе хлоридов калия и натрия. Концентрация солей соответствует температурам плавления льда $-3,5 . . .-0,3{ }^{\circ} \mathrm{C}$ и равна $0,5-5,7$ мас. $\% \mathrm{NaCl}$-экв. Газовая фаза представляет смесь углекислоты и метана.

В кварцевых жилах $I V$ в виде тонкой вкрапленности и прожилков проявлена висмутовая минерализация, которой сингенетичны первичные и псевдовторичные ФВ в кварце. Первичные VL ФВ (рис. 3, ж) гомогенизируются в жидкость в интервале температур $T_{\text {гом }} 340-350{ }^{\circ} \mathrm{C}$. Температуры эвтектики $T_{\text {эвт }}-12 \ldots-10{ }^{\circ} \mathrm{C}$ соответствуют наличию хлоридов калия и натрия в растворе. Характерные температуры плавления льда $\left(T_{\text {пл }}\right)$ ФВ такого вида и генерации находятся в интервале от -7 до $-6{ }^{\circ} \mathrm{C}$, 
соответствующие значения концентраций растворов равны 9,2-10,5 мас. \% NaCl-экв. Доминантным компонентом газовой фазы является углекислота, однако повсеместно присутствует примесь метана и сероводорода (редко следы азота и водорода). Примечательно, что в течение некоторых криометрических измерений VL ФВ (рис. 3, з) наблюдалось формирование каемки жидкой углекислоты. При последующем нагревании препарата происходила гомогенизация углекислоты в газ при температурах $T_{\text {гом }} \mathrm{CO}_{2}-7 \ldots-6{ }^{\circ} \mathrm{C}$. Рассчитанная плотность составляет $\rho \mathrm{CO}_{2} \approx 0,08$ г/ $\mathrm{cm}^{3}$, а давление оценивается в 1500-1700 бар. Псевдовторичные VL ФВ отличаются более низкими температурами гомогенизации (в жидкость) $T_{\text {гом }} 205-245^{\circ} \mathrm{C}$. Исходя из схожих с первичными VL $\Phi$ В значений температур эвтектики $T_{\text {эвт }}-11 \ldots-10{ }^{\circ} \mathrm{C}$, раствор также содержит хлори- ды калия и натрия. Концентрация солей для псевдовторичных VL $\Phi$ В с $T_{\text {пл }}-4 . . .-3{ }^{\circ} \mathrm{C}$ несколько ниже

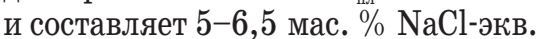

Белухинское месторождение. Редкометальная минерализация Белухинского месторождения локализуется в кварц-топаз-мусковитовых грейзенах (Bel-1-1, Bel-1-3) с вольфрамитом, пиритом и халькопиритом и в кварцевых жилах с вольфрамитом, молибденитом, пиритом и халькопиритом (Bel-1-2). Формированию рудных минералов кварц-топаз-мусковитовых грейзен, образующих вкрапленники и прожилки, сингенетичны первичные и псевдовторичные ФВ в кварце и топазе. Кварц содержит первичные VL ФВ, характеризующиеся температурами гомогенизации в жидкость от 285 до $325^{\circ} \mathrm{C}$. Полученные температуры эвтектики попадают в диапазон $T_{\text {эвт }}-23 . . .-21^{\circ} \mathrm{C}$, что ука-

таблица. Результаты микротерлометрии и Ралан-спектроскопии флюидных включений

Table. $\quad$ Results of microthermometry and Raman spectroscopy of fluid inclusions

\begin{tabular}{|c|c|c|c|c|c|c|c|c|c|c|c|}
\hline \multirow{2}{*}{ 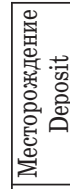 } & \multirow[t]{2}{*}{$\begin{array}{l}\text { Образец } \\
\text { Sample }\end{array}$} & \multirow{2}{*}{$\begin{array}{c}\text { Минеральная } \\
\text { ассоциация } \\
\text { Mineral } \\
\text { assosiation }\end{array}$} & \multirow{2}{*}{$\begin{array}{c}\text { Тип ФВ, } \\
\text { минерал- } \\
\text { хозяин } \\
\text { FI type, } \\
\text { host-mineral }\end{array}$} & \multirow[t]{2}{*}{ 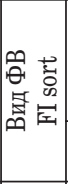 } & $\begin{array}{l}\mathrm{T}_{\text {эвт }} \\
\mathrm{T}_{\mathrm{eu}}\end{array}$ & $\begin{array}{c}\mathrm{T}_{\text {пл }} \\
\mathrm{T}_{\text {ice melt }}\end{array}$ & \multirow{2}{*}{$\begin{array}{c}\text { Соленость (мас. } \\
\% \text { NaCl-экв.) } \\
\text { Concentration } \\
\text { (wt. \% NaCl-eq.) }\end{array}$} & $\begin{array}{l}\mathrm{T}_{\text {rom }} \\
\mathrm{T}_{\text {hom }}\end{array}$ & $\begin{array}{l}\mathrm{T}_{\text {rom }} \\
\mathrm{T}_{\text {hom }} \\
\mathrm{CO}_{2}\end{array}$ & \multirow{2}{*}{$\begin{array}{l}\text { Давление } \\
\text { (бар) } \\
\text { Pressure } \\
\text { (bar) }\end{array}$} & \multirow[t]{2}{*}{$\begin{array}{l}\text { Состав газовой фазы } \\
\text { Gas phase composition }\end{array}$} \\
\hline & & & & & \multicolumn{2}{|c|}{$-{ }^{\circ} \mathrm{C}$} & & \multicolumn{2}{|c|}{${ }^{\circ} \mathrm{C}$} & & \\
\hline \multirow{15}{*}{ 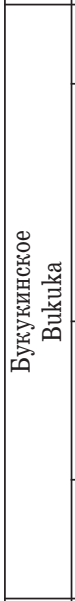 } & \multirow{2}{*}{ Buk-1 } & \multirow{2}{*}{1} & п, $\mathrm{q} / \mathrm{p}, \mathrm{q}$ & $\mathrm{VL}$ & $28-37$ & $5-6$ & $7,9-9,2$ & $290-310$ & н.о. & н.о. & $\mathrm{CH}_{4}+\mathrm{CO}_{2} \pm \mathrm{N}_{2}$ \\
\hline & & & пв, q/ps, q & VL & $14-17$ & $0,5-4$ & $0,9-6,5$ & $220-250$ & н.о. & н.о. & $\mathrm{CO}_{2} \pm \mathrm{CH}_{4}$ \\
\hline & \multirow{6}{*}{$\begin{array}{l}\text { Buk-2-1, } \\
\text { Buk-2-2 }\end{array}$} & \multirow{6}{*}{2} & $\Pi, \mathrm{q} / \mathrm{p}, \mathrm{q}$ & VL & $21-23$ & $5-7$ & $7,9-10,5$ & н.о. & н.о. & н.о. & $\mathrm{CO}_{2}+\mathrm{CH}_{4} \pm \mathrm{N}_{2} \pm \mathrm{H}_{2}$ \\
\hline & & & пв, q/ps, q & $\mathrm{VL}$ & H.0. & $2-6$ & $3,4-9,2$ & $250-280$ & н.о. & H.0. & $\mathrm{CO}_{2} \pm \mathrm{CH}_{4}$ \\
\hline & & & п, be/p, be & VL & $19-21$ & $1,5-3,5$ & $2,6-5,7$ & $240-320$ & н.о. & н.о. & $\mathrm{CH}_{4}+\mathrm{CO}_{2} \pm \mathrm{N}_{2} \pm \mathrm{H}_{2}$ \\
\hline & & & п, be/p, be & VLC & н.о. & н.о. & н.о. & $250-280$ & $28-30$ & $2000-2100$ & $\mathrm{CO}_{2}$ \\
\hline & & & п, be/p, be & VLS & н.о. & н.о. & н.о. & н.о. & н.о. & н.о. & $\mathrm{CO}_{2}+\mathrm{CH}_{4}$ \\
\hline & & & вт, be/s, be & $\mathrm{VL}$ & н.о. & $2,5-5$ & $4,2-7,9$ & $140-190$ & н.о. & н.о. & $\mathrm{CO}_{2} \pm \mathrm{CH}$ \\
\hline & \multirow{4}{*}{$\begin{array}{c}\text { Buk-3-1, } \\
\text { Buk-3-2 }\end{array}$} & \multirow{4}{*}{3} & $\Pi, q / p, q$ & $\mathrm{VL}$ & $10-15$ & $0,1-1,5$ & $0,2-2,6$ & $285-325$ & н.о. & н.о. & $\mathrm{CO}_{2}+\mathrm{CH}_{4}+\mathrm{H}_{2} \mathrm{~S} \pm \mathrm{N}_{2} \pm \mathrm{H}_{2}$ \\
\hline & & & $\Pi, q / p, q$ & VLC & H.о. & H.о. & н.о. & $295-310$ & $14-27$ & $1600-1700$ & $\mathrm{CO}_{2}$ \\
\hline & & & $\Pi, q / p, q$ & VLS & н.о. & н.о. & $43,8-46,4$ & $365-390$ & н.о. & н.о. & $\mathrm{CO}_{2}+\mathrm{CH}_{4}+\mathrm{H}_{2} \mathrm{~S} \pm \mathrm{N}_{2}$ \\
\hline & & & пв, q/ps, q & $\mathrm{VL}$ & $9-17$ & $0,3-3,5$ & $0,5-5,7$ & $190-260$ & H.о. & H.о. & $\mathrm{CO}_{2}+\mathrm{CH}_{4}$ \\
\hline & \multirow{3}{*}{ Buk-4 } & \multirow{3}{*}{4} & $\Pi, q / p, q$ & $\mathrm{VL}$ & $10-12$ & $6-7$ & $9,2-10,5$ & $340-350$ & н.о. & н.о. & $\mathrm{CO}_{2}+\mathrm{CH}_{4}+\mathrm{H}_{2} \mathrm{~S} \pm \mathrm{N}_{2} \pm \mathrm{H}_{2}$ \\
\hline & & & $\Pi, q / p, q$ & VLC & H.о. & н.о. & H.о. & $340-350$ & $-7 \ldots-6$ & $1500-1700$ & $\mathrm{CO}_{2}$ \\
\hline & & & пв, q/ps, q & VL & 10-11 & $3-4$ & $5-6,5$ & $205-245$ & н.о. & н.о. & $\mathrm{CO}_{2}+\mathrm{CH}_{4}$ \\
\hline \multirow{6}{*}{ 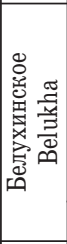 } & \multirow{5}{*}{$\begin{array}{l}\text { Bel-1-1, } \\
\text { Bel-1-3 }\end{array}$} & \multirow{5}{*}{5} & п, q/p, q & $\mathrm{VL}$ & $21-23$ & $0,1-1,5$ & $0,2-2,6$ & $285-325$ & н.о. & н.о. & $\mathrm{CO}_{2}+\mathrm{CH}_{4}+\mathrm{H}_{2} \mathrm{~S}$ \\
\hline & & & $\Pi, q / p, q$ & VLC & н.о. & н.о. & н.о. & $300-320$ & $9-12$ & $1200-1500$ & $\mathrm{CO}_{2}$ \\
\hline & & & п, q/p, q & VLS & н.о. & н.о. & $38,9-40,6$ & $310-330$ & н.о. & н.о. & $\mathrm{CO}_{2}+\mathrm{CH}_{4}$ \\
\hline & & & пв, q/ps, q & $\mathrm{VL}$ & $23-28$ & $2,5-3,5$ & $4,2-5,7$ & $240-260$ & н.о. & н.о. & $\mathrm{CO}_{2}$ \\
\hline & & & п, to $/ \mathrm{p}$, to & $\mathrm{VL}$ & H.о. & $2-4$ & $3,4-6,5$ & $290-350$ & н.о. & н.о. & $\mathrm{CO}_{2}+\mathrm{CH}_{4}+\mathrm{H}_{2} \mathrm{~S}$ \\
\hline & Bel-1-2 & 6 & п, q/p, q & $\mathrm{VL}$ & $7-17$ & $3-4$ & $5-6,5$ & $300-360$ & н.о. & н.о. & $\mathrm{CO}_{2}+\mathrm{CH}_{4}$ \\
\hline \multirow{2}{*}{ 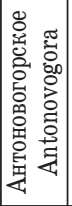 } & \multirow{2}{*}{ AG-1 } & \multirow{2}{*}{1} & п, $\mathrm{q} / \mathrm{p}, \mathrm{q}$ & VL & н.о. & $2,5-4$ & $4,2-6,5$ & $220-285$ & н.о. & н.о. & $\mathrm{CO}_{2} \pm \mathrm{CH}_{4}$ \\
\hline & & & $\Pi, q / p, q$ & VLC & н.о. & н.о. & н.о. & $240-260$ & $-2,5 \ldots-1,5$ & $750-850$ & $\mathrm{CO}_{2}$ \\
\hline
\end{tabular}

Примечания: $n$ - первичное, пв - псевдовторичное, вт - вторичное; н.о. - параметр не определен, q- квари, бе - берилл, tо - топаз. 1 квариевые жилы с вольфрамитом и пиритом; 2 - квари-берилл-мусковитовые грейзины с вольфрамитом, пиритом и молибденитол; 3 квариевые жилы с пиритом, галенитом и вольфрамитом; 4 - квариевые жилы с вислутином, пиритом и вольфралитол; 5 - кваритопаз-мусковитовые грейзены с вольфралитом, пиритол и халькопиритол; 6 - квариевые жиль с вольфралитол, молибденитол, пиритол и халькопиритол.

Notes: $p$ - primary, ps - pseudosecondary, s- secondary; н.o. - value is undefined, q-quartz, be - beryl, to - topaz. 1 - quartz veins with wolframite and pyrite; 2 - quartz-beryl-muscovite greisen with wolframite, pyrite and molybdenite; 3 - quartz veins with pyrite, galena and wolframite; 4 - quartz veins with bismuthinite, pyrite and wolframite; 5 - quartz-topaz-muscovite greisen with wolframite, pyrite and chalcopyrite; 6 - quartz veins with wolframite, molybdenite, pyrite and chalcopyrite. 
зывает на присутствие в растворе хлоридов натрия и калия. Для этих ФВ определены температуры плавления льда $T_{\text {пл }}-1,5 \ldots-0,1{ }^{\circ} \mathrm{C}$ и концентрации солей 0,2-2,6 мас. \% NaCl-экв. Газовая фаза представлена углекислотой и метаном, в отдельных случаях с примесью сероводорода. Для отдельных первичных ФB VL вида установлено отделение каемки жидкой углекислоты в результате понижения температуры. Ее гомогенизация в процессе последующего нагревания происходит в газовую фазу при температурах $T_{\text {гом }} \mathrm{CO}_{2} 9-12^{\circ} \mathrm{C}$, при полной гомогенизации включений в интервале температур 300-320 ${ }^{\circ} \mathrm{C}$. C помощью программного обеспечения получены оценки плотности углекислоты и давления: $\rho \mathrm{CO}_{2}, 0,13-0,14$ г/ $\mathrm{cm}^{3}, 1200-1500$ бар. Первичные VLS (рис. $3, u)$ ФВ гомогенизируются в интервале температур $310-330{ }^{\circ} \mathrm{C}$, что соответствует концентрации солей 38,9-40,6 мас. \% NaCl-экв. Газовая фаза является смесью углекислоты и метана.

В составе газовой фазы доминирует углекислота. В топазе изучались первичные ФВ вида VL (рис. $3, \kappa)$. Для них установлены температуры гомогенизации $T_{\text {гом }} 290-350{ }^{\circ} \mathrm{C}$ (в жидкость), температуры плавления льда $T_{\text {пл }}-4 . . .-2{ }^{\circ} \mathrm{C}$ и соленость 3,4-6,5 мас. \% NaCl-экв. Смесь углекислоты и метана представляет газовую фазу, редко определяется примесь сероводорода.

Для псевдовторичных VL ФВ в кварце индикаторным является интервал температур гомогенизации $T_{\text {гом }} 240-260{ }^{\circ} \mathrm{C}$ (в жидкость). Согласно температурам эвтектики $T_{\text {әвт }}$ от -28 до $-23{ }^{\circ} \mathrm{C}$ в растворе присутствуют хлориды натрия, калия и железа. Температуры плавления льда $T_{\text {пл }}-3,5 \ldots-2,5{ }^{\circ} \mathrm{C}$, соленость флюида варьирует от 4,2 до 5,7 мас. \%

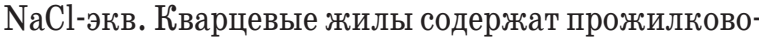
вкрапленную минерализацию, представленную вольфрамитом, молибденитом, пиритом и халькопиритом. В препаратах диагностированы первичные ФВ VL вида (рис. $3, л)$, отвечающие условиям формирования рудных минералов. Для таких включений получены температуры гомогенизации $300-360{ }^{\circ} \mathrm{C}$. Температуры эвтектики $\left(-17 \ldots-7{ }^{\circ} \mathrm{C}\right)$ отвечают раствору хлоридов натрия и калия. Оценка концентрации солей по температурам плавления льда $-4 . . .-3{ }^{\circ} \mathrm{C}$ составляет $5-6,5$ мас. $\%$

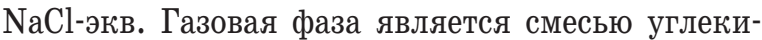
слоты и метана.

Антоновогорское месторождение. Рудная минерализация, представленная вкрапленностью вольфрамита и пирита, сосредоточена в кварцевых жилах (AG-1). Для определения физико-химических параметров ее формирования были диагностированы первичные ФВ в кварце вида VL (рис. 3, л). По данным исследований они характеризуются относительно невысокими температурами гомогенизации $T_{\text {гом }} 220-285{ }^{\circ} \mathrm{C}$ (в жидкость). Основываясь на температурах эвтектики $T_{\text {эвт }}-9 . . .-8{ }^{\circ} \mathrm{C}$ солевой состав раствора хлоридный, основные катионы - калий, натрий и магний. Температуры плавления льда $T_{\text {пл }}-4 \ldots-2,5{ }^{\circ} \mathrm{C}$, концентрация солей в растворе меняется в пределах 4,2-6,5 мас. \% $\mathrm{NaCl-экв.}$
В составе газовой фазы преобладает углекислота, в исключительных случаях примесь метана. Криометрия выявила феномен гомогенизации углекислоты в газовую фазу при температурах $T_{\text {гом }} \mathrm{CO}_{2}-2,5 \ldots-1,5{ }^{\circ} \mathrm{C}$. Полная гомогенизация таких ФВ происходит в жидкость при температурах $T_{\text {гом }} 240-260{ }^{\circ} \mathrm{C}$. Эти данные позволили рассчитать плотность углекислоты $\rho \mathrm{CO}_{2} \approx 0,09$ г/ $\mathrm{cm}^{3}$ и давление флюида 750-850 бар.

\section{Обсуждение результатов}

Рассмотренный ряд минеральных ассоциаций возник в результате многостадийного развития гидротермальных систем, связанных с интрузиями кукульбейского и, вероятно, шахтаминского комплексов. Исследование фазового состава, измерение температур гомогенизации, эвтектики и плавления льда показывают, что на начальном этапе из хлоридных высокотемпературных растворов шло формирование кварц-берилл-мусковитовых и кварц-топаз-мусковитовых грейзен. Кварц-берилл-мусковитовые грейзены Букукинского месторождения формировались из высоко- и среднетемпературных флюидов (240-320, 350-390 $\left.{ }^{\circ} \mathrm{C}\right)$, насыщенных углекислотой и восстановленными газами, преобладающим из которых является метан, в меньшей степени азот и водород. В растворе присутствуют хлориды натрия и калия. Совместное нахождение ФВ с жидкой углекислотой и газово-жидких ФВ с рудным минералом в берилле может свидетельствовать о вскипании флюида в момент захвата [12]. По температурам гомогенизации углекислоты установлены достаточно высокие значения давления минералообразования 2-2,1 кбар, соответствующие умеренным глубинам ( 8 км). Рудоносные флюиды кварц-топаз-мусковитовых грейзен Белухинского месторождения средне- и высокотемпературные $\left(240-260,285-350{ }^{\circ} \mathrm{C}\right)$. В составе газовой фазы повсеместно отмечаются содержания углекислоты, в отдельных случаях - примесь метана и сероводорода. В растворе определены (установлено присутствие) хлориды натрия и калия. Давление в момент рудообразования можно определить, как 1,2-1,5 кбар.

Последующими за грейзенами образованиями можно считать кварцевые жилы с преобладающим рудным минералом - вольфрамитом. На Букукинском месторождении кварцевые жилы с вольфрамитом и пиритом образовывались из высокотемпературного $\left(290-310{ }^{\circ} \mathrm{C}\right)$ хлоридного флюида с умеренными концентрациями солей при постепенном понижении температуры $\left(220-250{ }^{\circ} \mathrm{C}\right)$. Можно отметить смену катионного состава растворов: железо и натрий на натрий и калий. В составе газовой фазы присутствуют: углекислота, метан и азот. Кварцевые жилы с вольфрамитом, молибденитом, пиритом и халькопиритом Белухинского месторождения кристаллизовались при участии высокотемпературных $\left(300-360{ }^{\circ} \mathrm{C}\right)$ слабо концентрированных флюидов (до 6,5 мас. \% $\mathrm{NaCl}$-экв.), газовая фаза которых представлена смесью угле- 
кислоты и метана. Солевой состав раствора включает хлориды натрия и калия. Кварцевые жилы с вольфрамитом и пиритом Антоновогорского месторождения формировались при участии среднетемпературных $\left(220-285{ }^{\circ} \mathrm{C}\right)$ флюидов с низкой концентрацией солей (до 6,5 мас. \% NaCl-экв.). В состав газовой фазы входят углекислота с примесью метана. Для Антоновогорского месторождения получены наиболее низкие значения давления 0,75-0,85 кбар.
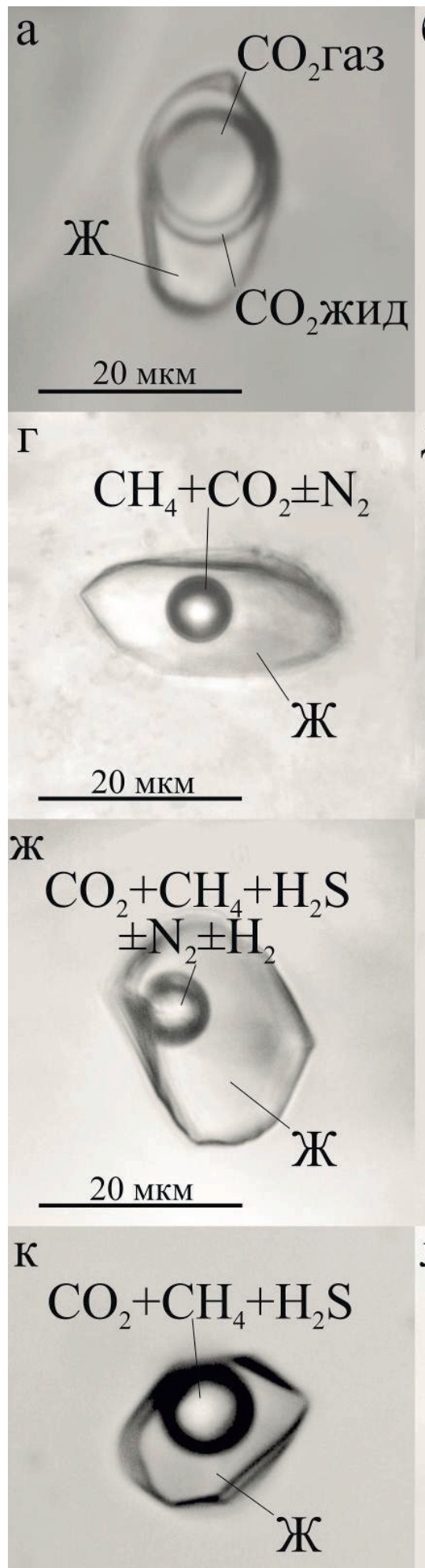

$15 \mathrm{MKM}$
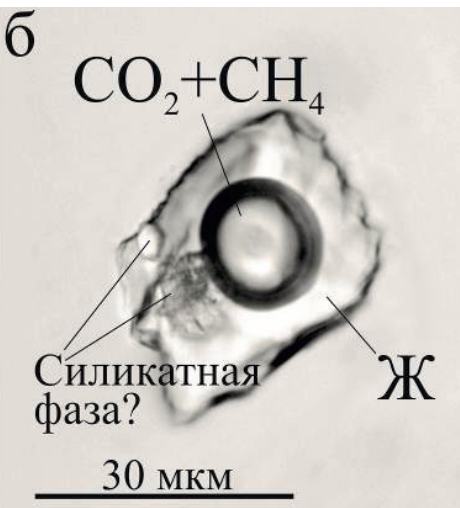

Д
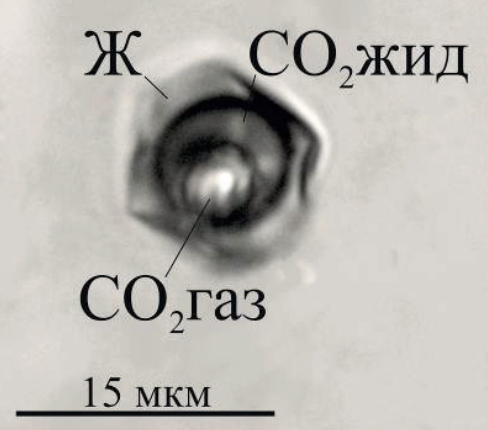

3

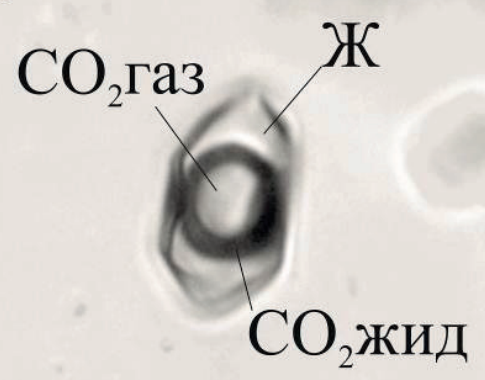

20 мКм

Л

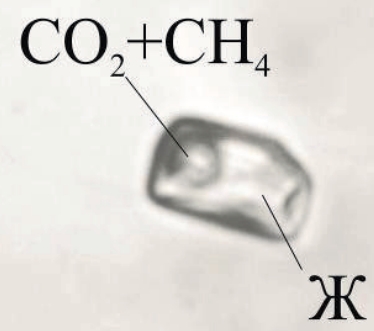

30 MKM

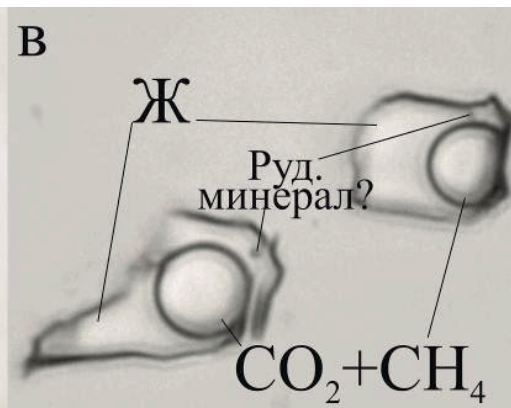

30 МКМ

e

$\mathrm{CO}_{2}+\mathrm{CH}_{4}+\mathrm{H}_{2} \mathrm{~S} \pm \mathrm{N}_{2}$ Ж
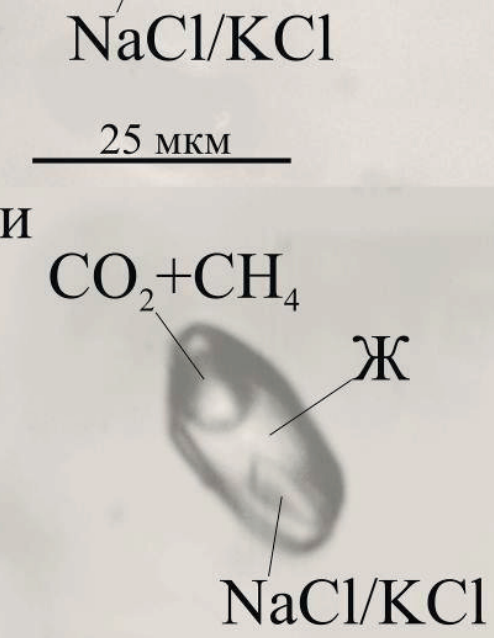

20 мкм

M

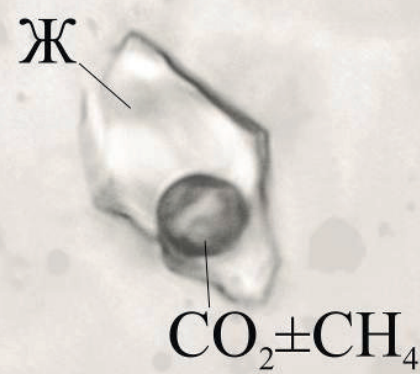

15 мКм 
На Букукинском месторождении также проявлены вольфрамит-галенит-пирит-кварцевая и вольфрамит-пирит-висмутин-кварцевая минеральные ассоциации. Формирование первой шло при участии хлоридно-натрово-калиевых высокотемпературных (290-390 $\left.{ }^{\circ} \mathrm{C}\right)$ и высококонцентрированных (до 46,4 мас. \% $\mathrm{NaCl}$-экв.) флюидов в условиях снижения температуры $\left(190-260{ }^{\circ} \mathrm{C}\right)$ и концентрации солей (до 0,2 мас. \% NaCl-экв.). Coстав газовой фазы отличается разнообразием: доминирующий компонент - углекислота, примесь метана и сероводорода, следы азота и водорода. Можно отметить, что первичные VLC и VLS ФВ находятся вместе, и это, вероятно, указывает на гетерогенный захват [13]. Вторая минеральная ассоциация отлагалась из высокотемпературных $\left(340-350{ }^{\circ} \mathrm{C}\right)$ флюидов с умеренной концентрацией солей $(9,2-10,5$ мac. \% NaCl-экв.). В растворе обнаружены хлориды калия и натрия. В составе газовой фазы выявлена углекислота, как главный компонент, метан и сероводород в качестве примесей, следы азота и водорода. Полученные оценки давления для обеих минеральных ассоциаций близки и составляют 1,5-1,7 кбар.

Все изученные нами минеральные ассоциации сформировались при участии хлоридных высокотемпературных флюидов, насыщенных углекислотой. Повсеместно рудоносные флюиды содержат восстановленные газы, из которых превалирует метан, а сероводород, азот и водород находятся в подчиненном количестве. Следует отметить постепенное снижение температуры в процессе формирования каждой отдельно взятой минеральной ассоциации. Катионный состав растворов относительно стабилен. В ранних растворах главную роль среди катионов играл натрий, меньшую - калий. Более поздние растворы содержали преимущественно калий, в подчиненном количестве - натрий. Были полученные умеренные значения оценки глубин образования руды. Месторождение Букукинское является наиболее глубинным из рассматриваемых объектов (6-8 км). Наиболее приближенное к поверхности месторождение по полученным данным Антоноворское (3-3,5 км), что может объяснять наименьшее разнообразие компонентов газовой фазы. По совокупности эмпириче- ских данных можно предположить, что рудообразующий флюид являлся магматическим (отделялся от ближнего ассоциирующего плутона) [14].

Полученные данные о возрасте оруденения позволяют рассмотреть вопрос о генетической связи с конкретными магматическими комплексами. Так, полученный $\mathrm{Ar}-\mathrm{Ar}$ возраст по Букукинскому месторождению хорошо согласуется с данными, полученными Л.Ф. Сырицо и др. [15]. Возраст формирования кварц-вольфрамитовых жил и даек риолитпорфиров ( $\mathrm{Rb}-\mathrm{Sr}$ и $\mathrm{Sm}-\mathrm{Nd}$ системы) составляет $138,7 \pm 1,5$ и $138 \pm 1,9$ млн лет соответственно. Совпадающие в пределах погрешности возраст и первичное отношения стронция даек и кварц-вольфрамитовых жил при значении величины $\varepsilon \mathrm{Nd}=-3,6$ дают основание предполагать их одновременное формирование и, вероятно, единый источник. Полученные нами данные о возрасте вольфрамового оруденения Букукинского и Антоновогорского месторождений позволяют предположить генетическую связь с магматическими породами кукульбейского комплекса, возраст которых оценивается 145-132 млн лет [15]. В то же время полученный позднеюрский возраст кварц-вольфрамитовых жил Белухинского месторождения наводит на мысль 0 связи вольфрамового оруденения с шахтаминским интрузивным комплексом. Близкие значения возраста получены для многих золоторудных и комплексных золотосодержащих месторождений Восточного Забайкалья, которые находятся в тесной пространственной и генетической связи с магматическими породами шахтаминского комплекса [16-20]. Формирование вольфрамового оруденения на Белухинском месторождении может быть связано или со становлением заключительных фаз шахтаминского комплекса, или с наиболее ранними фазами кукульбейского комплекса, для прояснения этого вопроса требуется проведения изотопно-геохронологических исследований магматических пород, развитых в пределах месторождения.

\section{Заключение}

Редкометальная минерализация Кукульбейского рудного района, на примере Букукинского, Белухинского и Антоновогорского месторождений, формировалась при участии высокотемпера-

Рис. 3. Флюидные включения. Первичные ФВ Букукинского месторождения: квари-берилл-мусковитовых грезен с вольфралитол, пиритом и молибденитом в берилле видов VLC (a) и VLS (б, в); квариевых жил с вольфрамитом и пиритом в кварие вида VL (г); квариевых жил с пиритом, галенитом и вольфрамитом в кварие видов VLC (ә) и VLS (е); квариевых жил с висмутином, пиритом и вольфрамитом в кварие видов VL ж) и VLC (3). Первичные ФВ Белухинского месторождения: квари-топаз-мусковитовых грейзен в кварие вида VLS (u) и в топазе вида VL (к); квариевых жил с вольфрамитом, молибденитом, пиритом и халькопиритом в кварие вида VL (л). Первичные ФВ Антоновогорского месторождения квариевых жил с вольфрамитом и пиритом в

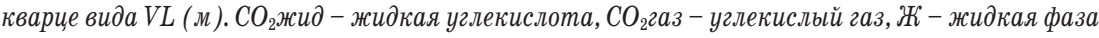

Fig. 3. Fluid inclusions. Primary FI of the Bukuka deposit: quartz-beryl-muscovite greisen with wolframite, pyrite and molybdenite in beryl VLC-type (a) and VLS-type (б, в); quartz veins with wolframite and pyrite in quartz VL-type (2); quartz veins with pyrite, galena and wolframite in quartz VL-type ( $\partial$ ) and VLS-type (e); quartz veins with bismuthinine, pyrite and wolframite in quartz VL-type (ж) and VLC-type (3). Primary FI of the Belukha deposit: quartz-topaz-muscovite greisen in quartz VLS-type (u) and in topaz VL-type ( $\kappa$ ); quartz veins with wolframite, molybdenite, pyrite and chalcopyrite in a quartz VL-type ( $\pi$ ). Primary FI of the Antonovogora deposit of quartz veins with wolframite and pyrite in quartz VL-type (m). $\mathrm{CO}_{2} \nVdash u \partial-$ liquid carbon dioxide, $\mathrm{CO}_{2} 2 \mathrm{a}_{3}-$ gaseous carbon dioxide, 3 liquid phase 
турных гидротермальных углекислотно-воднохлоридных растворов. Характерной чертой рудоносных флюидов является насыщенность восстановленными газами, такими как метан, сероводород, азот и водород. В течение формирования отдельных минеральных ассоциаций прослеживается эволюционный характер изменения физико-химических условий: понижение температуры и солености флюида и уменьшение разнообразия в составе газовой фазы. Обнаружены свидетельства эпизодического вскипания растворов, которое, вероятно, способствовало разрушению рудоносных комплексов и отложению рудных минералов. Рудообразование протекало в условиях умеренных давлений, на глубинах от 8 км (для Букукинского

\section{СПИСОК ЛИТЕРАТУРЫ}

1. Kozlov V.D. Trace-element composition and origin of granitoids from the Shakhtama complex and Kukul'bei rare-metal complex (Aga zone, Transbaikalia) // Russian Geology and Geophysics. 2011. - V. 52. - Iss. 5. - P. 526-536.

2. Лазько Е.М., Ляхов Ю.В., Пизнюр А.В. Физико-химические основы прогнозирования постмагматического оруденения (по термобарогеохимическим данным). - М.: Недра, 1981. - 256 с.

3. Физико-химические условия формирования редкометального $\mathrm{W}-\mathrm{Mo}(\mathrm{Bi})$ оруденения Восточного Забайкалья: на примере Шахтаминского, Букукинского, Белухинского и Антоновогорского месторождений / А.А. Редина, Ю.О. Редин, И.Р. Прокопьев, В.Ф. Дульцев / / Основные проблемы в учении об эндогенных рудных месторождениях: новые горизонты. Сборник материалов Всероссийской конференции, посвященной 120-летию со дня рождения выдающегося российского ученого академика А.Г. Бетехтина. - М.: ИГЕМ РАН, 2017. - С. 218-221.

4. Гайворонский Б.А. Букукинское месторождение // Месторождения Забайкалья. - Чита; М.: Геоинформмарк, 1995. - Т. 1. Кн. 1. - С. $146-148$.

5. Скурский М.Д. Недра Забайкалья. - Чита: Читинская Областная Типография, 1996. - 692 с.

6. Thermochronology of the Chernorud granulite zone, Ol'khon region, Western Baikal area / A.V. Travin, D.S. Yudin, A.G. Vladimirov, S.V. Khromykh, N.I. Volkova, A.S. Mekhonoshin, T.B. Kolotilina // Geochemistry international. - 2009. - V. 47. № 9. - P. 1107-1124.

7. Fleck R.J., Sutter J.F., Elliot D.H. Interpretation of discordant ${ }^{40} \mathrm{Ar} /{ }^{39} \mathrm{Ar}$ age-spectra of mesozoic tholeiites from antarctica //Geochimia et cosmihimia acta. - 1977. - V. 41. - № 1. - P. 15-32.

8. Roedder E. Fluid inclusions: Reviews in Mineralogy - Washington: Mineralogical Society of America, 1984. - $644 \mathrm{p}$.

9. Борисенко А.С. Анализ солевого состава растворов газово-жидких включений в минералах методом криометрии // Использование методов термобарогеохимии при поисках и изучении рудных месторождений. - М.: Недра, 1982. - С. 37-46.

10. Bodnar R.J., Vityk M.0. Interpretation of microthermometric data for $\mathrm{H} 2 \mathrm{O}-\mathrm{NaCl}$ fluid inclusions // Fluid inclusions in minerals: methods and applications. - Blacksburg, VA: Virginia Tech, 1994. - P. 117-130 месторождения) до 3 км (для Антоновогорского месторождения). По полученным термобарогеохимическим данным можно сделать вывод о магматической природе рудообразующего флюида. Проведенные изотопно-геохронологические исследования показали, что формирование вольфрамового оруденения Кукульбейского рудного района происходило в поздней юре - раннем мелу и связано со становлением магматических пород кукульбейского комплекса. Однако не исключено, что позднеюрское оруденение генетически связано со становлением пород шахтаминского комплекса.

Работа выполнена в рамках Государственного задания, проект № 0330-2016-0001 и проект № 0330-2016-0002, а также при поддержке гранта РФФИ № 16-35-00253.

11. Brown P.E. FLINCOR: a microcomputer program for the reduction and investigation of fluid-inclusion data // American Mineralogist. - 1989. - V. 64. - № 11-12. - P. 1390-1393.

12. Higgins N.C. Fluid inclusion evidence for the transport of tungsten by carbonate complexes in hydrothermal solutions // Canadian Journal of Earth Sciences. - 1980. - V. 17. - №. 7. P. 823-830.

13. Wilkinson J.J. Fluid inclusions in hydrothermal ore deposit // Lithos. - 2001. - V. 55. - Iss. 1-4. - P. 229-272.

14. Pirajno F. Hydrothermal processes and mineral systems. - Dordrecht: Springer, 2009. $-1250 \mathrm{p}$.

15. Продуктивность редкометальных плюмазитовых гранитов и условия образования месторождений вольфрама / Л.Ф. Сырицо, Е.В. Баданина, В.С. Абушкевич, Е.В. Волкова, А.В. Терехов // Геология рудных месторождений. - 2018. - Т. 60. № 1. - C. 38-56.

16. Спиридонов А.М., Зорина Л.Д., Китаев Н.А. Золотоносные рудно-магматические системы Забайкалья. - Новосибирск: Академическое издательство «ГЕ0», 2006. - 291 с.

17. The Zhireken porphyry Mo ore-magmatic system (Eastern Transbaikalia): U-Pb age, sources, and geodynamic setting / A.P. Berzina, A.N. Berzina, V.O. Gimon, V.Y. Kiseleva, S.V. Palesskii, T.B. Bayanova, R.S. Krymskii, E.N. Lepekhina // Russian Geology and Geophysics. - 2015. - V. 5. - № 3. - P. 446-465.

18. Redin Yu.O., Dultsev V.F., Nevolko P.A. Gold-bismuth mineralization of the Lugokan ore field (Eastern Transbaikalia): age, mineral composition and relationship with magmatism // Ore Geology Review. - 2015. - V. 70. - P. 228-240.

19. New data on the age of gold mineralization of the Lugokan ore cluster (Eastern Transbaikalia) / Yu.0. Redin, V.F. Dultsev, P.A. Nevolko, A.V. Ponomarchuk // Doklady Earth Sciences. 2016. - V. 469. - Iss. 2. - P. 851-854.

20. The large Bystrinskoe $\mathrm{Cu}-\mathrm{Au}$-Fe deposit (eastern trans-Baikal region): Russia's first example of a skarn-porphyry ore-forming system related to adakite / V.A. Kovalenker, S.S. Abramov, G.D. Kiseleva, T.I. Krylova, Y.I. Yazykova, N.S. Bortnikov // Doklady Earth Sciences. - 2016. - V. 468. - Iss. 2. - P. 566-570.

Поступила 28.02.2019 г.

\section{Информация об авторах}

Peдина A.A., младший научный сотрудник Института геологии и минералогии им. В.С. Соболева СО РАН.

Мокрушников В.П., младший научный сотрудник Института геологии и минералогии им. В.С. Соболева СО РАН.

Peдuн Ю.О., кандидат геолого-минералогических наук, научный сотрудник Института геологии и минералогии им. В.С. Соболева СО РАН. 
UDC 553.46(550.83:550.93)

\title{
FORMATION CONDITIONS AND AGE OF THE RARE-METAL MINERALIZATION OF THE KUKULBEY ORE REGION (EASTERN TRANSBAIKALIA)
}

\author{
Anna A. Redina', \\ redina@igm.nsc.ru \\ Viktor P. Mokrushnikov', \\ viktorm@igm.nsc.ru \\ Yury 0. Redin', \\ redin@igm.nsc.ru \\ ' V.S. Sobolev Institute of Geology and Mineralogy of the SB RAS,
3, Academician Koptyug avenue, Novosibirsk, 630090, Russia.
}

The relevance of the research. Identification of conditions, sources, movements and sequence of formation of rare metal concentrations in different geological settings is primary and fundamental issues of ore geology and geochemistry. To come up with this one the authors have determined the formation conditions of rare-metal mineralization by modern methods and, furthermore, carried out isotope-geochronological investigations, based on the study of the typical deposits of the Kukulbey ore region.

The main aim is to obtain new data on physico-chemical conditions for formation of rare metal mineralization, and determine the age of mineralization.

Objects of the research are Bukuka, Belukha and Antonovogora deposits.

Methods. Fluid inclusions were studied in polished thin sections by cryo-thermometry and Raman spectroscopy. Cryo-thermometric studies were carried out in the THERM-600 microcooler from Linkam. The samples were successively cooled to $-190{ }^{\circ} \mathrm{C}$ and heated until the substance of inclusions was completely homogenized. During the observation, the temperatures of the eutectic, melting of ice and homogenization were measured. Melting temperatures of ice for two-phase fluid inclusions and melting of salt crystals for three-phase allowed establishing the concentration of salts in terms of $\mathrm{NaCl}$-equivalent. The composition of gas and mineral phases of the fluid inclusions was studied by Raman spectroscopy - the Ramanor U-1000 spectrometer and the Horiba DU420E-OE-323 detector from Jobin Yvon, the Millennia Pro laser from Spectra-Physics; Confocal Raman Microscope alpha 300R from WITec. ${ }^{40} \mathrm{Ar} /{ }^{39} \mathrm{Ar}$ method of isotopegeochronological dating by the method of stepwise heating was used to establish the absolute age of mineralization.

Results. Ore mineral associations of these deposits were formed from chloride high-temperature fluids saturated with carbon dioxide. Ore-bearing fluids ubiquitously contain reduced gases. The dominant one is methane, hydrogen sulfide, nitrogen and hydrogen are subordinate gases. The authors have traced an evolution of ore-bearing fluid within the crystallization of individual mineral associations: decrease in temperature and concentration of the solutions and conversion of cationic composition from essentially sodium to essentially potassium. Moderate estimates of depths were obtained: 6-8 km for the Bukuka, 4,5-6 km for the Belukha and 3-3,5 km for the Antonovogora deposit. The age of rare metal mineralization is established at Antonovogora deposit - 146,7 $11,7 \mathrm{Ma}$ (muskovite from

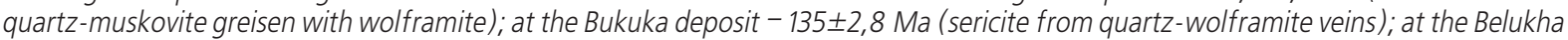
deposit - 155,6 $61,8 \mathrm{Ma}$ (sericite from quartz-wolframite veins).

Conclusions. Rare-metal mineralization of the Kukulbey ore region, based on the Bukuka, Belukha and Antonovogora deposits, was formed from high-temperature hydrothermal solutions of magmatic origin saturated with reduced gases (methane, hydrogen sulphide, nitrogen and hydrogen). The crystallization depth varies from 8 to $3 \mathrm{~km}$. According to isotope-geochronological studies the formation of tungsten mineralization within the Kukulbey ore region occurred in the Late Jurassic-early Cretaceous. Thus, rare-metal deposits of this area are probably associated with both the Kukulbey and the Shakhtama complexes.

\section{Key words:}

Rare-metal deposits, age, formation conditions, relations to magmatism, Eastern Transbaikalia.

The reported study was funded by the scope of the State task, project No. 0330-2016-0001 and 0330-2016-0002, and by RFBR according to the research project No. 16-35-00253.

\section{REFERENCES}

1. Kozlov V.D. Trace-element composition and origin of granitoids from the Shakhtama complex and Kukul'bei rare-metal complex (Aga zone, Transbaikalia). Russian Geology and Geophysics, 2011, vol. 52, Iss. 5, pp. 526-536.

2. Lazko E.M., Lyakhov Yu.V., Piznyur A.V. Fiziko-khimicheskie osnovy prognozirovaniya postmagmaticheskogo orudeneniya [Physico-chemical basis for predicting postmagmatic mineralization]. Moscow, Nedra Publ., 1981. 256 p.

3. Redina A.A., Redin Yu.0., Prokopyev I.R., Dultsev V.F. Fizikokhimicheskie usloviya formirovaniya redkometalnogo W-Mo (Bi) orudeneniya Vostochnogo Zabajkalya: na primere Shakhtaminskogo, Bukukinskogo, Belukhinskogo i Antonovogorskogo mesto- rozhdeniy [Formation conditions of rare-metal W-Mo (Bi) mineralization of the Eastern Transbaikalia: by the example of the Shakhtama, Bukuka, Belukha and Antonovogora deposits]. Osnounye problem $v$ uchenii ob endogennykh rudnykh mestorozhdeniyakh: novye gorizonty. Sbornik materialov konferentsii, posvyashchennoy 120-yu letiyu so dnya rozhdeniya vydayushchegosya rossiyskogo uchenogo akademika A.G. Betekhtina [The main problems in the study of endogenous ore deposits: new horizons. Proc. of the All-Russian Conference, dedicated to the $120^{\text {th }}$ anniversary of the birth of the outstanding Russian academician A.G. Bethetein]. Moscow, IGEM RAS, 2017. pp. 218-221.

4. Gaivoronskii B.A. Bukukinskoe mestorozhdenie [Bukukinskoe deposit]. Mestorozhdeniya Zabaikalya [Deposits of Transbaikalia]. Chita, Geoinformmar Publ., 1995. Vol. 1, B. 1, pp. 146-148. 
5. Skursky M.D. Nedra Zabaikalya [The depths of the Transbaikal]. Chita, Chita Regional Printing Office, 1996. 692 p.

6. Travin A.V., Yudin D.S., Vladimirov A.G., Khromykh S.V., Volkova N.I., Mekhonoshin A.S., Kolotilina T.B. Thermochronology of the Chernorud granulite zone, 0l'khon region, Western Baikal area. Geochemistry international, 2009, vol. 47, no 9, pp. 1107-1124.

7. Fleck R.J., Sutter J.F., Elliot D.H. Interpretation of discordant ${ }^{40} \mathrm{Ar} /{ }^{39} \mathrm{Ar}$ age-spectra of Mesozoic tholeiites from antarctica. Geochimia et cosmihimia acta, 1977, vol. 41, no. 1, pp. 15-32.

8. Roedder E. Fluid inclusions: Reviews in Mineralogy. Washington, Mineralogical Society of America, 1984. $644 \mathrm{p}$.

9. Borisenko A.S. Analiz solevogo sostava rastvorov gazovo-zhidkikh vklyucheniy v mineralakh metodom kriometrii [Salt composition analysis of solutions of gas-liquid inclusions in minerals using the cryometry method]. Ispolzovanie metodov termobarogeokhimii pri poiskakh i izuchenii rudnykh mestorozhdeniy [The use of thermobarogeochemical methods in the search and study of ore deposits]. Moscow, Nedra Publ., 1982. pp. 37-46.

10. Bodnar R.J., Vityk M.O. Interpretation of microthermometric data for $\mathrm{H}_{2} \mathrm{O}-\mathrm{NaCl}$ fluid inclusions. Fluid inclusions in minerals: methods and applications. Blacksburg, VA, Virginia Tech, 1994. pp. $117-130$.

11. Brown P.E. FLINCOR: a microcomputer program for the reduction and investigation of fluid-inclusion data. American Mineralogist, 1989, vol. 64, no. 11-12, pp. 1390-1393.

12. Higgins N.C. Fluid inclusion evidence for the transport of tungsten by carbonate complexes in hydrothermal solutions. Canadian Journal of Earth Sciences, 1980, vol. 17, no. 7, pp. 823-830.

13. Wilkinson J.J. Fluid inclusions in hydrothermal ore deposit. Lithos, 2001, vol. 55, Iss. 1-4, pp. 229-272.
14. Pirajno F. Hydrothermal processes and mineral systems. Dordrecht, Springer, 2009. $1250 \mathrm{p}$.

15. Syritso L.F., Badanina E.V., Abushkevich V.S., Volkova E.V., Terekhovc A.V. Fertility of rare-metal peraluminous granites and formation conditions of tungsten deposits. Geology of Ore Deposits, 2018, vol. 60, no. 1, pp. 38-56. In Rus.

16. Spiridonov A.M., Zorina L.D., Kitaev N.V. Zolotonosnye rudnomagmaticheskie sistemy Zabaikalya [Gold-bearing Ore-magmatic Systems of Transbaikalia]. Novosibirsk, Academic publishing house «GE0", 2006. $291 \mathrm{p}$.

17. Berzina A.P., Berzina A.N., Gimon V.O., Kiseleva V.Y., Palesskii S.V., Bayanova T.B., Krymskii R.S., Lepekhina E.N. The Zhireken porphyry Mo ore-magmatic system (Eastern Transbaikalia): U-Pb age, sources, and geodynamic setting. Russian Geology and Geophysics, 2015, vol. 5, no. 3, pp. 446-465.

18. Redin Yu.O., Dultsev V.F., Nevolko P.A. Gold-bismuth mineralization of the Lugokan ore field (Eastern Transbaikalia): age, mineral composition and relationship with magmatism. Ore Geology Review, 2015, vol. 70, pp. 228-240.

19. Redin Yu.O., Dultsev V.F., Nevolko P.A., Ponomarchuk A.V. New data on the age of gold mineralization of the Lugokan ore cluster (Eastern Transbaikalia). Doklady Earth Sciences, 2016, vol. 469, Iss. 2, pp. 851-854.

20. Kovalenker V.A., Abramov S.S., Kiseleva G.D., Krylova T.I., Yazykova Y.I., Bortnikov N.S. The large Bystrinskoe $\mathrm{Cu}-\mathrm{Au}-\mathrm{Fe}$ deposit (eastern trans-Baikal region): Russia's first example of a skarn-porphyry ore-forming system related to adakite. Doklady Earth Sciences, 2016, vol. 468, Iss. 2, pp. 566-570.

Received: 28 February 2019.

\section{Information about the authors}

Anna A. Redina, junior researcher, V.S. Sobolev Institute of Geology and Mineralogy of the SB RAS.

Viktor P. Mokrushnikov, engineer, V.S. Sobolev Institute of Geology and Mineralogy of the SB RAS.

Yury O. Redin, Cand. Sc., researcher, V.S. Sobolev Institute of Geology and Mineralogy of the SB RAS. 